\title{
Transformation of Social and Environmental Views during the Sporting Events (On an Example of the Kazan Universiade 2013)
}

\author{
Zamaletdinov R. \\ Kazan (Volga Region) Federal University, Kazan \\ i.ricinus@rambler.ru, pankorn@rambler.ru
}

Kornilov P.

Kazan National Research Technological University

Mingazova N.

Kazan (Volga Region) Federal University, Kazan

Dautov A.

Kazan (Volga Region) Federal University, Kazan

Doi:10.5901/mjss.2014.v5n18p235

\section{Abstract}

The article considers the issues of transformation of social and environmental systems from the standpoint of social constructivist approach during carrying out Kazan Universiade 2013. Designing an image of sport achievements fosters a positive range in assessing of big city environmental issues. Publication based on the study of sociological questionnaire of citizens and guests of Kazan in the area of the Universiade venues during its implementation.

\section{Introduction}

XXVII World Summer Universiade, which was held in Kazan in July 2013 has become one of the highlights of the sport world. It became a milestone not only in development of domestic youth sport, but all sport in general.

Significant increase in the number of major sports events held in our country so far not reflected in similar number of studies of the impact on various aspects of life. At the moment it became apparent that it is impossible to adequately analyze the parameters of significance of the event only for the economy or socio-cultural development of the region. Therefore, the theoretical basis for research of the Universiade 2013 influence on the city and the region development was the concept of sustainable territorial development.

Social and environmental topic of the impact of sport events on the development of the region has not received enough deep analysis in our country. This aspect seems to be promising in terms of forecasting the social response on occurring during the preparation and conducting the competition transformations.

Kazan already has existed successful research directed on environmental and sociological issues. In this study the most pressing environmental issues of the city were identified. However, during the preparation for the Universiade an integrated approach requires which is linked by the organization of a major international sporting event.

\section{Materials and Methodic Approaches}

This article presents the results of the analysis of social and environmental research which was carried out on the territory of Kazan during the XXVII World Summer Universiade 2013.

Our focus turned to the relationship between human being and environment of its habitat, showing the transformation of the mental field and symbolic reality.

The study is the result of an interdisciplinary synthesis of social environment, sociology, etc. Analysis of the 
processes of designing has been made from the standpoint of contextual constructivist approach. Interdisciplinary synthesis will be implemented on the basis of methodology of sociological and mental research and design ${ }^{1}$. The constructionist approach to investigation of social issues showed the most clear and consistent subjectively position. The main ideas of this approach were formulated by Malcolm Spector and John Kitsyuzom in $1970^{2}$. Since that time debate about the appropriate degree of subjectivity in this area flashed among adherents of constructivist approach.

Radical constructionist approach actually rejects any objective basis in carrying out. This point has undergone a serious and quite reasonable criticism. At first John Serls ${ }^{3}$ addressed with this point, and later Joel Best ${ }^{4}$ wrote his work about the limitations of rigorous constructivist approach.

The contextual approach to the design allows the existence of more objective conditions, which can serve as the background and a starting point of reference for the study. For example, sociological and mental reality of the Universiade and the use of various environmental measurements and surveys presented us itself as a kind of context in our study. The key approach of collecting material for the study was an anonymous questionnaire.

The aim of our study was to investigate the construction of environmental attitudes and perceptions during carrying out such major sporting events as well as analysis of the defining factors of process. The material for this study was a survey in which 1671 respondents participated during the the duration of the Universiade.

The survey was conducted in the vicinity of 14 competition venues during the Universiade competitions. Respondents were asked about the state of the environment of the city of Kazan, its dynamics, especially regard for the Universiade. Basic theoretical and methodological approaches have become the concept of social environment, mentology and constructivist approach ${ }^{5,6,7,8,9}$. The main emphasis was placed on environmentalism as a trend associated with the construction of environmental culture and attitudes of mass consciousness.

Each questionnaire included 10 questions:

1. What effect of organization and conduction of the Universiade 2013 on environmental condition Kazanka river?

2. How do you think whether the environmental condition of Kazanka river enough for requirements of the Kazan Universiade 2013?

3. What effect on the ecological condition of the lake Middle Kaban has occurred during the process of organizing and carrying out the Universiade 2013?

4. How do you think whether the environmental condition of lake Middle Kaban enough for requirements of the Kazan Universiade 2013?

5. What effect of organization and conduction of the Universiade 2013 on the quality of drinking water?

6. How do you think, whether the quality of drinking water changed in Kazan over the last 5 years?

7. What effect of organization and conduction of the Universiade 2013 on air quality?

8. How do you think, whether the air quality changed in Kazan over the last 5 years?

9. What effect of organization and conduction of the Universiade 2013 on landscaping in Kazan?

10. How do you think, whether the landscaping changed in Kazan over the last 5 years?

For questions 1, 3, 5, 7 and 9, the following response options were offered: neutral, positive, negative, adverse, hard to answer. For questions 2, 4, 6, 8 and 10 the following response options were offered: enough, not enough, hard to answer.

\footnotetext{
${ }_{1}^{1}$ Kornilov P.A. Gender construction in war images in mass sociocultural communication // The Family in the Modern World / Materials of International scientic conference (Helsinki, April, 30, 2011). - Helsinki, 2011. - 318 p. - P. 118-123.

${ }^{2}$ Spector M., Kitsuse J.I. Constructing Social Problems, Menlo Park, 1977.

${ }^{3}$ Searle, John. The Construction of Social Reality. - New York: Free Press, 1995. - P. 56. - 256 p.

${ }^{4}$ Best, Joel. But seriously folks: the limitations of the strict constructionist interpretation of social problems // Constructionist controversies: issues in social problems theory / Ed. by G. Miller, J. A. Holstein. Hawthorne, NY: Aldine de Gruyter, 1993. P. 109-127.

${ }^{5}$ Petulla J. American environmentalism: Values, tactics, priorities. -L., 1980.

${ }^{6}$ Adoni, H. Media and the social construction of reality: (Toward an integration of theory and research) / H. Adoni, Sh/ Mane // Communication research. - 1984. - Vol.11 - № 3.

${ }^{7}$ Berger, P. L., Luckmann, T. The Social Construction of Reality. A Treatise on sociology of Knowledge. 1966.

${ }^{8}$ Champagne, P. La construction mediatique des «malaises sociaux» / P. Champagne // Actes de la recherche en sciences socials. 1991. - № 9. - P. 64-75.

${ }^{9}$ Cook, F. Media and agenda setting: effects on the public, interest group leaders, policy makers, and policy / T. Tyler., G. Edward, M. Gordon, D. Protess, D. Leff, H. Molotch // The public opinion quarterly. - 1983. - Vol. 47. - № 1.
} 


\section{Results and Discussion}

Sociological survey was conducted among 1671 respondents on 14 competition venues of the Universiade. Age of respondents varies from 7 to 88 years. $66.7 \%$ of them - the citizens of Kazan, $33.3 \%$ - guests of the Universiade. Social composition of the respondents is as follows: $31.9 \%$ - are workers, $26.2 \%$ - students, $18 \%$ - employees, $11.5 \%$ pensioners, $12.4 \%$ - other.

Selecting the location of surveys was not accidental. Objects as material symbols of the Universiade facilitate for positioning of respondents. Respondent person, even if he was just passing through feels an association with the place. For example, the construction of a large expensive sporting facility may be associated with a waste of money and resources, pollution, etc. Or maybe associations will be positive. Thus, the mental field that occurs around objects will have an impact on the answers for this survey.

Table 1. Summarizes the results of the survey

\begin{tabular}{|c|c|c|c|c|c|c|c|c|c|c|c|}
\hline \multirow[b]{2}{*}{ 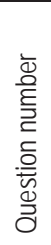 } & \multicolumn{11}{|c|}{ Answers, $\%$} \\
\hline & 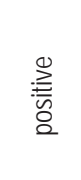 & $\begin{array}{l}\text { 등 } \\
\text { 응 }\end{array}$ & 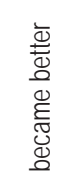 & 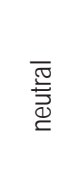 & 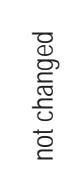 & 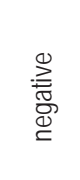 & $\begin{array}{l}\Phi \\
\frac{\omega}{\Phi} \\
\stackrel{\Xi}{0}\end{array}$ & 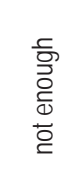 & 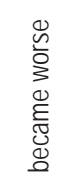 & 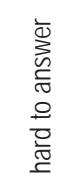 & 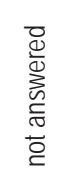 \\
\hline 1 & 28,37 & - & - & 26,87 & - & 17,47 & 5,63 & - & - & 20,05 & 0,12 \\
\hline 2 & - & 35,37 & - & - & - & - & - & 33,99 & - & 28,37 & 0,78 \\
\hline 3 & 38,18 & - & - & 22,14 & - & 12,51 & 2,39 & - & - & 23,1 & 0,18 \\
\hline 4 & - & 44,4 & - & - & - & - & - & 23,4 & - & 29,98 & 0,72 \\
\hline 5 & 14,84 & - & - & 47,64 & - & 12,63 & 4,01 & - & - & 18,97 & 0,42 \\
\hline 6 & - & 0 & 16,64 & - & 42,85 & - & - & - & 19,99 & 20,41 & 0,42 \\
\hline 7 & 18,07 & - & - & 44,88 & - & 18,49 & 4,55 & - & - & 9,99 & 2,51 \\
\hline 8 & - & - & 14,72 & - & 30,94 & - & - & - & 36,8 & 14,3 & 1,74 \\
\hline 9 & 81,27 & - & - & 8,2 & - & 3,531 & 1,44 & - & - & 2,81 & 1,26 \\
\hline 10 & - & - & 71,57 & 0 & 11,67 & - & - & - & 5,87 & 8,14 & 5,45 \\
\hline
\end{tabular}

The study of environmental conditions in Kazan is conducting over the years. The results were presented in numerous publications $10,11,12,13,14$, which allowed us to evaluate specific aspects of the environmental conditions in Kazan by the current moment and in dynamics.

Comparison analysis showed significant differences among the respondents in the perception and evaluation of the environment and the picture that consists, according to official data and the results of research of the Department of Environmental Engineering and Water Management of Kazan Federal University. For example, the majority of

\footnotetext{
${ }^{10}$ Mingazova N. Inventory of small lakes as the preservation method under the conditions of a big city and industrial region (Russia) / Lakes, rivers, groundwater and coastal areas: understanding linkages. Abstracts of 14 th World Lake Conference. -Austin, Texas USA, 2011. - P. 94.

${ }_{11}^{11}$ Mingazova N. Middle Volga Lakes of Russia: Typology, Biodiversity, Ecological problems and Restoration Opportunities // Global Threats of Large Lakes: Managing in an Environment of Instability and Uppredisstability. Abstracts of 46th Conference on Great Lake Research, 10th World Lake Conference. June 22-26, 2003, DePaul University, Chicago, Illinois, USA. - P. 241.

12 Mingazova N., Derevenskaya O., Barieva F., Pavlova L. Restoration of Low Kaban Lake (Kazan, Russia): 25-term experience of restoration and monitoring of ecological condition // 13th World Lake Conference. Abstract Volume. Wuhan-China, 2009. - P. 299-305.

${ }^{13}$ Mingazova N., Derevenskaya O., Palagushkina O., Nabeeva E., Zamaletdinov R., Zaripova N. The Biodiversity of water objekts of Urban Territories (Kazan, Russia) // Conference proceedings. ICEAS. The 3nd International Conference on Engineering and Applied Science. LSBE. The 2nd International Conference on Life Science and Biological engineering. ACCMES. The 2nd Asian Conference on Civil, Materials and Environmental Sciences. November, 2013. Osaka, Japan. - P. 401-407.

${ }_{14}$ Mingazova N.M., Yupina G.A., Derevenskaya O.Yu., Illarionova M.N. Ecology. Environment. Water bodies and green areas. // Urban revitalization and redevelopment of Volga district territories in the city of Kazan (Center Waterfront Area of Volga River). International Urban design workshop. Background information. - Kazan, 2008. - P. 24-25.
} 
respondents gave positive evaluation to the questions about the Kazanka River and the lake Middle Kaban.

To the question "What effect of organization and conduction of the Universiade 2013 on environmental condition Kazanka river?" 28\% answered positively, 27\% - neutral, 17\% - negative, 6\% - adverse, 20\%. - were undecided. Ha вопрос «Как Вы считаете, соответствует ли экологическое состояние р. Казанка требованиям для проведения Универсиады 2013 в г. Казани?» ответили: соответствует - 35\%, не соответствует - 34\%, затруднились с ответом $-28 \%$, не ответили $-1 \%$.

To the question «What effect on the ecological condition of the lake Middle Kaban has occurred during the process of organizing and carrying out the Universiade 2013» 38\% answered positively, 22\% - neutral, 12\% - negative, 2\% adverse, $23 \%$ - were undecided.

To the question «How do you think whether the environmental condition of Lake Middle Kaban enough for requirements of the Kazan Universiade 2013» 44\% answered enough, 23\% - not enough, 30\% - were undecided, 1\% not answered.

In fact what is happening is reversed. During the construction of the Universiade venues, filling work on floodplain and partially water area were held in the mouth of the Kazanka River as well as straightening and partial filling the shores of Lake Middle Kaban. All this had a negative impact on the water bodies, worsened the hydrological conditions, water quality and environmental data status of water bodies.

Opposite trend with questions «What effect of organization and conduction of the Universiade 2013 on the quality of drinking water?», « How do you think, whether the quality of drinking water changed in Kazan over the last 5 years?», « What effect of organization and conduction of the Universiade 2013 on air quality?», « How do you think, whether the air quality changed in Kazan over the last 5 years?». Respondents, in their responses tended a negative assessment. However in reality measures to clean water and air quality were carried out according to the Ministry of Environment and Natural Resources of the Republic of Tatarstan for 2012 year. Due to this qualitative improvement has been observed. The main reasons were given: the transition in the Republic of Tatarstan to more environmentally friendly gasoline and use of new technologies in water reservoirs.

Only the last two questions «What effect of organization and conduction of the Universiade 2013 on landscaping in Kazan?» and «How do you think, whether the landscaping changed in Kazan over the last 5 years?» we can observe the respondents' environmental evaluation in coincidence with official data. About $90 \%$ of participating of the questionnaire was satisfied with the greening, the remaining $10 \%$ expressed their dissatisfaction with the state of urban landscaping. In fact, the degree of of landscaping of the city during Universiade has declined steadily, leading to the necessity of largescale urban greening. And in this regard before the Universiade about 47,800 trees and 19,600 shrubs were planted due the municipal program "Green record".

Thus, our study showed that people's ideas about the state of the environment in the absence of visible and clear criteria for such assessment depends very little on actual realities, which is shown by environmental research. The vast majority of respondents had no information on the results of environmental monitoring in the Kazan city. Their ideas were based on the instantaneous evaluation available single visual observations. It can be stated that the construction of environmental concepts and facilities shall be determined entirely by other factors.

Nowadays it is apparent that the environmental situation in big cities is intense and the citizens often dissatisfied with state of the environment. In this regard large-scale construction and interference in the environment had to add negativity in the respondents' answers, but it did not happen. In general, we can note a positive trend in the estimates of the respondents and the negative reviews are insignificant in amount. A high level on neutral positions shows restraint of respondents who probably realize that the environmental conditions are objectively poor, but nevertheless do not express negative evaluation considering it untimely.

The main reasons for this is that the Universiade 2013 has acquired the image of a victorious sport war. Initially obtaining the right of this sporting event was presented as a great victory for itself. Modern mentology notes that «the main symbolic substitute of war currently the sport».

\section{Conclusion}

With a positive background holding sports events sharpness of environmental issues smoothed and goes into secondary importance.

Results of a poll not correspond to the results of environmental researches. Activating the archetype of war in sports leads to the fact that environmental issues are of concern less and victory gives an excuse of damage. Thus, the construction of environmental attitudes and perceptions within the framework of the Universiade 2013 in Kazan and ahead of the Olympics 2014 in Sochi acquired specific nature and special features. 
It is likely that the effect of a specific atmosphere of competitions left their mark on the environmental assessment. In the case of surveys long before the Universiade or in the absence of brilliant victories of Russiat team, environmental assessments of respondents likely would have sounded harsher and more negative. Victorious war sports designs positive perception of the environment because in such conditions people in a relationship with the environment feel like winners.

\section{Acknowledgments}

The authors sincerely thank members of the Laboratory of Water Ecosystems Optimization, as well as teachers and students of the Department of Environmental Engineering and Water Management which is part of Institute of Management and Territorial Development of Kazan (Volga Region) Federal University for assistance in the collection of primary data. The work was supported by the ANO, «Executive Board of the XXVII World Summer Universiade 2013 in Kazan» under the agreement on assessing the impact of the XXVII World Summer Universiade on the development of the city and region, as well as by grant from the Kazan Federal University to carry out state assignment in the field of scientific activity.

\section{References}

Adoni, H. Media and the social construction of reality: (Toward an integration of theory and research) / H. Adoni, Sh/ Mane // Communication research. - 1984. - Vol.11 - № 3.

Berger, P. L., Luckmann, T. The Social Construction of Reality. A Treatise on sociology of Knowledge. 1966.

Best, Joel. But seriously folks: the limitations of the strict constructionist interpretation of social problems // Constructionist controversies: issues in social problems theory / Ed. by G. Miller, J. A. Holstein. Hawthorne, NY: Aldine de Gruyter, 1993. P. 109-127.

Champagne, P. La construction mediatique des "malaises sociaux" / P. Champagne // Actes de la recherche en sciences socials. 1991. - № 9. - P. 64-75.

Cook, F. Media and agenda setting: effects on the public, interest group leaders, policy makers, and policy / T. Tyler., G. Edward, M. Gordon, D. Protess, D. Leff, H. Molotch // The public opinion quarterly. - 1983. - Vol. 47. - № 1.

Kornilov P.A. Gender construction in war images in mass sociocultural communication // The Family in the Modern World / Materials of International scientic conference (Helsinki, April, 30, 2011). -Helsinki, 2011. - 318 p. - P. 118-123.

Mingazova N. Inventory of small lakes as the preservation method under the conditions of a big city and industrial region (Russia) I Lakes, rivers, groundwater and coastal areas: understanding linkages. Abstracts of 14 th World Lake Conference. -Austin, Texas USA, 2011. - P. 94.

Mingazova N. Middle Volga Lakes of Russia: Typology, Biodiversity, Ecological problems and Restoration Opportunities // Global Threats of Large Lakes: Managing in an Environment of Instability and Uppredisstability. Abstracts of 46th Conference on Great Lake Research, 10th World Lake Conference. June 22-26, 2003, DePaul University, Chicago, Illinois, USA. - P. 241.

Mingazova N., Derevenskaya O., Barieva F., Pavlova L. Restoration of Low Kaban Lake (Kazan, Russia): 25-term experience of restoration and monitoring of ecological condition // 13th World Lake Conference. Abstract Volume. Wuhan-China, 2009. - P. 299-305.

Mingazova N., Derevenskaya O., Palagushkina O., Nabeeva E., Zamaletdinov R., Zaripova N. The Biodiversity of water objekts of Urban Territories (Kazan, Russia) // Conference proceedings. ICEAS. The 3nd International Conference on Engineering and Applied Science. LSBE. The 2nd International Conference on Life Science and Biological engineering. ACCMES. The 2nd Asian Conference on Civil, Materials and Environmental Sciences. November, 2013. Osaka, Japan. - P. 401-407.

Mingazova N.M., Yupina G.A., Derevenskaya O.Yu., Illarionova M.N. Ecology. Environment. Water bodies and green areas. // Urban revitalization and redevelopment of Volga district territories in the city of Kazan (Center Waterfront Area of Volga River). International Urban design workshop. Background information. - Kazan, 2008. - P. 24- 25.

Petulla J. American environmentalism: Values, tactics, priorities. L., 1980.

Searle, John. The Construction of Social Reality. - New York: Free Press, 1995. - P. 56. - 256 p.

Spector M., Kitsuse J.I. Constructing Social Problems, Menlo Park, 1977. 
